\title{
SONDERKOMMANDO DORA - SPECIAL MILITARY GEOSCIENTIFIC UNIT OF THE GERMAN COUNTER-INTELLIGENCE SERVICE IN NORTH AFRICA 1942
}

\author{
Hermann Häusler \\ University of Vienna, Austria
}

\begin{abstract}
The counter-intelligence service of the German Armed Forces High Command launched Operation Dora in 1941 to update terrain information of North Africa for the German warfare and to reconnoitre the frontier between Libya and Chad. This article presents Sonderkommando Dora as an example of military geoscientific reconnaissance during World War II in the North African theatre of war where the German Armed Forces needed more accurate military geographic information on the Western Desert. The scientific personnel comprised geographers, cartographers, geologists, astronomers, meteorologists and road specialists, and they prepared special maps on the environmental setting of the Libyan Sahara. As far as it is known, these special maps were never used by Axis troops (who fought in World War II against the Allies) for tactical purposes - although it cannot be ruled out that the maps provided general information on the proximity of the German Africa Corps, the Panzer Group Africa and of the Panzer Army Africa, respectively, and also of the retreating Army Group Africa.
\end{abstract}

\section{Introduction}

In January 1941, the counter-intelligence service of the German Armed Forces High Command (Oberkommando der Wehrmacht [OKW]), commanded by Admiral Wilhelm Canaris, launched Operation Dora to update terrain information of North Africa for the German warfare and to reconnoitre the frontier between Libya and Chad. Sonderkommando Dora was headed by an air force colonel, and had company status. It consisted of a military group of about 100 personnel and a scientific unit of about 10 military geoscientists, such as geographers, cartographers, geologists, astronomers, meteorologists and road specialists. The military scientific teams were fully motorised and supported by airplanes for reconnaissance flights. The head of the military geoscientific staff was the geographer Dr Otto Schulz-Kampfhenkel.

In the base camp Hon, $500 \mathrm{~km}$ south-southeast of Tripoli, two reconnaissance teams were formed, Eastern Patrol and Western Patrol, each comprising 10 personnel, seven wheeled vehicles and airplanes. Eastern Patrol reconnoitred the routes east of 
Djebel Haruj via Wau en Namus to Bir Bu Haschischa; Western Patrol reconnoitred part of Fezzan, from Murzuq in the east to Gatrun and Djebel ben Gnema. Both patrols provided cartographic maps of important routes crossing the Sahara in meridional direction at a scale of 1:200 000, including military geologic information on water supply, trafficability, natural obstacles and a map of magnetic deviation.

Morphologic-geologic maps were drawn based on the geologic mapping and reconnaissance flights, highlighting hamada (high rocky plateau, often with scarps), serir (gravel desert), ergs (areas of shifting sand dunes), dunes and oases. Oases were important for calculation of water supply, while mapping hamada, serir and dunes was important for calculating the off-road trafficability for armed forces. In total, Sonderkommando Dora provided 23 specialised maps at various scales, i.e. 1:25 000, 1:50 000, 1:200 000 and 1:1 million. Whereas the accuracy of official Italian topographic maps could be off by tens of kilometres, post-war validation of these maps updated by Sonderkommando Dora using high-resolution satellite images yielded inaccuracies at a maximum of 500 metres.

Independent of this military scientific special command, a second German Special Forces unit, Dora was also launched in western Libya, to which the Brandenburg Regiment was attached.

Only few articles have been published on Sonderkommando Dora, its orders and reconnaissance in central Libya as well as the geoscientific results thereof. This is not surprising because special command Dora was launched in January 1941 by AbwehrAbteilung I, the Counter-Intelligence Branch I of the German Armed Forces High Command. The military geoscientific mission of Sonderkommando Dora in Libya lasted from April 1942 to January 1943.

In 1951, one of the staff members of Sonderkommando Dora, the astronomer Dr Nikolaus Benjamin Richter, published a civil version of his journey to the Sahara, ${ }^{1}$ which was printed as second edition and commented on by Michael Rolke. ${ }^{2}$ Another expedition report was published by Richter in 1958, which was also reprinted and commented on as second edition by Michael Rolke, ${ }^{3}$ and many maps produced by this special command were published by him. ${ }^{4}$ Among others, scientific articles on geological observations during the 1942 mission of the special command were published by the geologists Dr Georg Knetsch and Dr Friedrich-Karl Mixius. ${ }^{5}$ Special geographic studies were performed by the cartographer Dr Wolfgang Pillewizer. ${ }^{6}$ Based on personal contacts with staff members of the German special command and archive studies, the geoscientific results of Sonderkommando Dora were documented by Hermann Häusler and later on cited by Sören Flachowsky and Holger Stoecker. A geomedical monograph series of Libya was published by the geographer and medical doctor Helmuth Kanter in $1967 .{ }^{7}$

Erwin $\mathrm{Schmidl}^{8}$ as well as Kuno Gross and others ${ }^{9}$ briefly refer to the mission of Sonderkommando Dora, the results of which had been published by Hermann Häusler ${ }^{10}$ and later on again by Wolfgang Kaufmann. ${ }^{11}$ In addition, Erwin Schmidl ${ }^{12}$ reported that locally and timely paralleling the military geoscientific Sonderkommando Dora, 
a purely military special command was detached to Libya, consisting of teams of the Brandenburg Regiment. Several authors dealing with Special Forces of World War II refer to this Brandenburger mission, which has also been termed Sonderkommando Dora. ${ }^{13}$ In addition to these two special commands, both termed Sonderkommando Dora, a further special command of Rommel's Afrika Korps to central Libya termed Unternehmen Dora ${ }^{14}$ is also reported. Because the Brandenburgers also supported the Panzerarmee Afrika in 1942 until the retreat following El Alamein, ${ }^{15}$ Kuno Gross and others concluded, "Till now not the slightest shred of evidence has been found to indicate that Unternehmen Dora really took place", and some confusion of these Dora missions can be recognised on the Internet. ${ }^{16}$

The intention of this article is to present results of Sonderkommando Dora as an example of military geoscientific reconnaissance during World War II in North Africa. Firstly, the reasons why the Supreme High Command of the German Armed Forces needed more accurate military geographic information on the Western Desert, in particular on the border region between Chad and Libya, are explained. This is followed by a description of the environmental settings regarding physical geography, ecoregions, geology and hydrogeology of the operational area of Sonderkommando Dora. In the next two sections, personnel and equipment of this special command as well as the results of the military geoscientific reconnaissance in Libya are outlined. In the above-mentioned context of varying Dora commands, an organigram of missions in North Africa is presented and discussed in the next section.

\section{Special missions of the Supreme High Command of the German Armed Forces in North Africa}

Special missions of the Oberkommando der Wehrmacht in North Africa are presented in a timeline of events that lasted from December 1940 to late 1942. On 10 June 1940, Italy declared war on France and the United Kingdom and Italian colonial forces in Libya launched the invasion of Egypt. From December 1940 to February 1941, British Empire forces attacked Italian forces in western Egypt and Cyrenaica during Operation Compass. On 22 January 1941, British troops occupied Tobruk, and on 9 February 1941, they occupied El Agheila. In January 1941, the oasis of Kufra was attacked by Free French from Equatorial Africa in concert with Long Range Desert Group patrols.

Following a meeting between Adolf Hitler and Benito Mussolini on 19 January 1941, the German Afrika Korps was formed by the Supreme High Command of German Armed Forces under the command of Lieutenant General Erwin Rommel. On 3 February 1941, Rommel was appointed head of the German Army troops in Africa. After arriving in Tripoli on 14 February, he reoccupied El Agheila on 24 February 1941. When the Afrika Korps shipped to Libya, so did the Brandenburgers. The men, raised as four companies of special Tropical Units, were fluent in either English or Arabic and used captured British vehicles to operate behind enemy lines in raids and reconnaissance missions, mirroring the actions of the British Long Range Desert Group (LRDG). ${ }^{17}$ 
Paralleling the advance of British troops in the Cyrenaica, in January 1941, Abteilung I of the Abwehr headquarters at the right time, the Foreign Intelligence Collection of the German counter-intelligence service (commanded by Colonel Hans Piekenbrock) launched Operation Theodora to update maps of North Africa for the German warfare and to reconnoitre the frontier between Libya and Chad (French Equatorial Africa). Major Franz Seubert headed Referat 2 of Army West (in charge of Near and Middle East as well as North Africa) and took charge of Operation Theodora, with the function of collecting information on the De Gaullist troops being massed under General Le Clerc in the Lake Chad area. ${ }^{18}$ In addition, Seubert was in charge of Operation Salam, Lázló Almásy's successful infiltration of two German spies in a manner similar to the Allied LRDG. ${ }^{19}$ Theodora comprised the unit Theo (for theoretic), which had been deployed to a station of Abwehrstelle VI located at Rheda near Münster (Germany) since 1 August 1941. Like others, this Abwehrstelle at Rheda was also subdivided into sections for espionage, sabotage and counter-intelligence. The formation of an expedition team in Berlin was named Dora I and the special detachment sent to Libya in April 1942 was termed Dora II or Sonderkommando Dora, which took action in Libya until December 1942 (Figure 1).

In January 1941, no military geography service was supporting higher commands with topographic maps because the Mapping and Survey Branch of the Army High Command was not launched before 1 November $1941 .{ }^{20}$ Hence, a meeting took place in Leipzig at the end of March 1941, where the following gentlemen agreed upon to support updating the French maps of North Africa and the Sahara for military purposes:

- Captain F Lumbeck, head of Abwehrstelle VI, the local station of German military intelligence in Münster (Westphalia);

- Dr R Reinhard, head of the Geographical Institute of Leipzig University;

- Dr Heinrich Schmitthenner, head of the Geographical Institute of Münster;

- Dr H Dörries, director of the Institute for Colonial Geography at the University of Leipzig and

- Dr Konrad Voppel, director in charge of the German Institute for Regional Studies. ${ }^{21}$

Referring to Mr Dines-Jones, Fellow of the Royal Geographical Society in London, as cited by Gross and others, ${ }^{23}$ a March 1941 expedition to Gatrun in the south of Libya by Gruppe Schwerin was known to the British as Unternehmen Dora. This mission was conducted at a distance of $2000 \mathrm{~km}$ by Gerhard Graf von Schwerin, who headed Special Purposes Regiment No. 200 of the $5^{\text {th }}$ Light Division as a reconnaissance mission for the German Afrika Korps. ${ }^{24}$ Later on, in April 1941, Gerhard von Schwerin led a long-range joint German and Italian commando force deep into the British Empire's lines in Libya to recapture the Mechili. This Unternehmen Dora of Rommel's $5^{\text {th }}$ Light Division in the Fezzan was basically a mission of the Army High Command, paralleling the preparation of the geoscientific mission of Sonderkommando Dora launched by the Foreign Intelligence Departments of Amt Ausland Abwehr at the right time. 


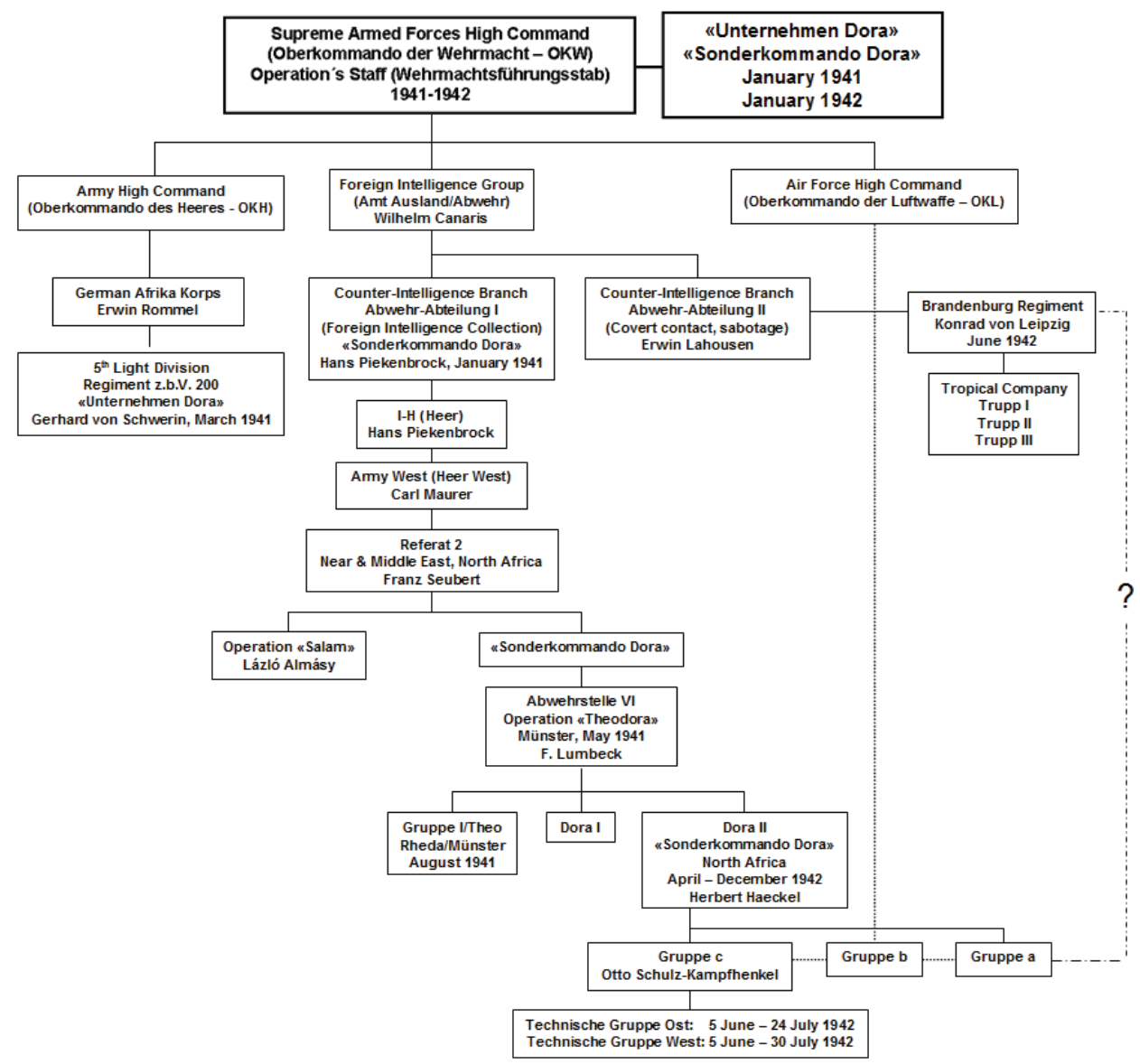

Figure 1: Tentative organigram of Operation Dora of Special Purposes Regiment 200 in the Fezzan and of Operation Theodora in 1941, the predecessor of Sonderkommando Dora in the chain of command of the Supreme High Command of the Armed Forces in January 1942 (modified later ${ }^{22}$ ). 
Figure 1 is a tentative organigram of the special missions in North Africa, first planned by the Supreme High Command of the Armed Forces on 26 January 1941 (Theodora), followed by the expedition of the $5^{\text {th }}$ Light Division (Unternehmen Dora) at the right time. When Operation Theodora ended after 10 months of intensive studies and preparation, in January 1942, Counter-Intelligence Abteilung I launched Sonderkommando Dora, the military geoscientific operation between Hon and the Tibesti massif, which is explained below.

According to a secret order of the German counter-intelligence service dated 27 March 1942, Abteilung I launched Sonderkommando Dora for which Foreign Intelligence Collection, Army West, was responsible. ${ }^{25}$ Sonderkommando Dora was a joint mission of the German armed forces and the air force, and received orders from several high commands, explicitly from -

- the Supreme High Command of the Armed Forces;

- the Army High Command;

- the Commander-in-Chief of the Luftwaffe;

- Panzerarmee Afrika; and

- the Commander-in-Chief in the South, who was basically subordinate to the Italian High Command (Comando Supremo).

Consequently, 24 offices were involved, including, amongst others, the central division of Wilhelm Canaris, the counter-intelligence branches Abwehr I, II and III as well as the local counter-intelligence stations Abwehrstelle III (Berlin) and VI (Münster).

It took ten months of preparation to set up Sonderkommando Dora as a mixed command. Its objective was to secure missing military information from areas of southern Libya that were not controlled by the Axis Forces, and to prepare a strong point at the southern Libyan border. The following comprises a list of orders given by various administrative departments:

- Supreme High Command of the Armed Forces, Operation's Staff: Creation of missing information for potential expedition-like operations in Central Africa and Sudan. Reconnaissance of possible bases for offences and defeat in the southern hills of the Sahara.

- Foreign Intelligence Group: Military reconnaissance and counter-intelligence of areas not controlled by the German-Italian troops or Italian security organs, in particular regarding the influence of British and Free French forces in Equatorial Africa. Counter-espionage (according to procedures of Abwehr-Abteilung III $\mathrm{F}$, responsible for foreign counter-espionage) comprising reconnaissance and control of enemy intelligence services east and south of the Panzerarmee Afrika as well as rearward of it.

- Army High Command: Obtaining missing special military geographic information, such as aerial photo maps, route maps and trafficability maps based on photogrammetric and geodetic survey. Creating a special military geology water supply map of the Middle Sahara. 
- Commander-in-Chief of the Luftwaffe: Obtaining missing aerial geographic, navigatory and meteorological information for a potential service of the air force in Inner Africa. Gaining tropical medical and troop hygienic experiences for future operations in tropical Africa.

Upon request of the Operations Staff of the Commander-in-Chief of the Luftwaffe, Abteilung I of the German counter-intelligence service specified in a letter dated 2 April $1942^{26}$ that the Sonderkommando Dora should comprise three units, termed Groups a-c: ${ }^{27}$

Group a) This unit for military reconnaissance and counter-intelligence was based in Hon and was ordered to collect - with a network of foreign agents and in accordance and cooperation with Groups b and c - intelligence on British and Free French troops in Inner Africa.

Group b) This unit for aerial reconnaissance and aerial stereo photo interpretation had to provide aerial photos and reconnoitre the area between Djebel Sauda and the Tibesti Massif, south of Hon. If needed, Group b had to support Group c, the military geoscientific group.

Group c) This unit had to collect military geography and military geology information as well as navigation information about the area between Djebel Sauda and the Tibesti. Group c was protected by a military command equipped with a light armoured reconnaissance vehicle. ${ }^{28}$

Sonderkommando Dora was commanded by Colonel Herbert Haeckel (at that time with Abwehr I, Referat 2) who later on also headed Group c in Libya. Because Group a of Sonderkommando Dora, responsible for military reconnaissance and counterintelligence, was ordered to obtain counter-intelligence using a network of foreign agents, it can be concluded that Abwehr-Abteilung II (headed by Colonel Erwin Lahousen-Vivremont) was also involved in this counter-espionage mission in southwestern Libya. It can only be assumed that, comparable to the March 1941 mission of Unternehmen Dora launched by the Regiment 200 z.b.V. (Gruppe Schwerin), another Unternehmen Dora was launched by Lieutenant Colonel Conrad von Leipzig in June 1942. ${ }^{29}$ Because the Brandenburg Regiment was attached to Abteilung II of the Abwehr, confusion arose in post-war literature about whether the counter-espionage mission in June 1942 was a mission performed by Group a of Sonderkommando Dora or a completely different mission of Abwehr II (also termed 'Unternehmen Dora'). Without providing any references, several authors describe in detail the deployment of 100 personnel of Brandenburg Regiment z.b.V. 800 in North Africa as another Unternehmen Dora launched by Abwehr II in June 1942. ${ }^{30}$ Up to now, this operation has been proved neither by interrogation protocols ${ }^{31}$ nor by archival documents on the activities of the Amt Ausland Abwehr in North Africa and therefore several historians doubt the existence of this operation. ${ }^{32}$

To sum up: it is more likely that activities of the Free French and LRDG in the proximity of Rommel's Panzerarmee Afrika increased in 1942 so that Group a of Sonderkommando Dora was reinforced by Brandenburgers for counter-intelligence 
and sabotage. In such a case, the entire Sonderkommando Dora would have remained an operation of Abwehr-Abteilung I. It is this variant, though questionable, which is favoured in Figure 1.

In late 1941, the Military Geography Service of the Army General Staff printed a special pamphlet on Tunisia including landscape photographs and maps as well as a brief military evaluation of the different landscapes. ${ }^{33}$ However, similar information on Libya and the environmental settings of the Western Desert has not been prepared by the Military Geography Service.

\section{Environmental settings of the Libyan Sahara}

An introduction to the geology, landscape and climate of Libya is presented as far as is relevant for understanding military geology of the North African theatre of war.

The short description of Libyan climate follows the explanations of the German geographer Dr Helmuth Kanter, who took part in the counter-intelligence campaign of the German Abwehr in Libya. ${ }^{34}$ Its climate is determined by the contrast between the Mediterranean and the Sahara. Climatic regions depend on the distance to the Mediterranean Sea. Along the coastal and hilly regions of northern Tripolitania and Cyrenaica Mediterranean coastal climate, coastal steppe climate and highland climate prevail with precipitation ranging from 100 to $400 \mathrm{~mm} /$ year. At a distance of $\sim 300 \mathrm{~km}$ to the south continental steppe climate (with $\sim 50-100 \mathrm{~mm}$ precipitation per year) is followed by semi-desert climate with less than $\sim 20 \mathrm{~mm} /$ year. Desert climate prevails in central and southern Libya, and south-eastern Libya is influenced by extreme desert climate with precipitation less than $5 \mathrm{~mm}$ /year. As a consequence, Libya is poor in water. It periodically receives rain in winter which falls largely in coastal areas and only irregularly reaches the interior. Nevertheless temporary springs or autumn floods can suddenly fill dry river beds (wadis) causing accidents.

In terms of geology Libya belongs entirely to the Saharan domain forming the northern part of the African Shield. Precambrian outcrops are rare in Libya. Sedimentation continued from the Cambrian Period throughout the Palaeozoic Era, but epirogenetic movements occurred from the beginning of the Ordovician Period. Subsidence continued during the Jurassic Period. In the Murzuq and Kufra Basins, Mesozoic continental sedimentation (of Nubian Sandstone, marl and gypsum) persisted until the Early Cretaceous. ${ }^{35}$ At the end of the Early Cretaceous, the Libyan tilt began. Existing basins became stable, while sinking occurred in the eastern part of the country, which became subsidised. The subsidence is irregular, according to different blocks of varying mobility. The transgression of the Tertiary sea from the eastern Mediterranean reached the Tibesti region in Early Eocene. The Oligocene is characterised by the formation of rifts in conjunction with the strains stretching the African block. The stratigraphic history of the northern Cyrenaica is linked to the unstable Tunisian platforms. Uplifting of this zone took place during the Eocene, and it became intensively folded during the Middle Miocene. The present margins of the Gulf of Sirte correspond to east-southeast-trending Pliocene flexures, followed by $\backslash$ 


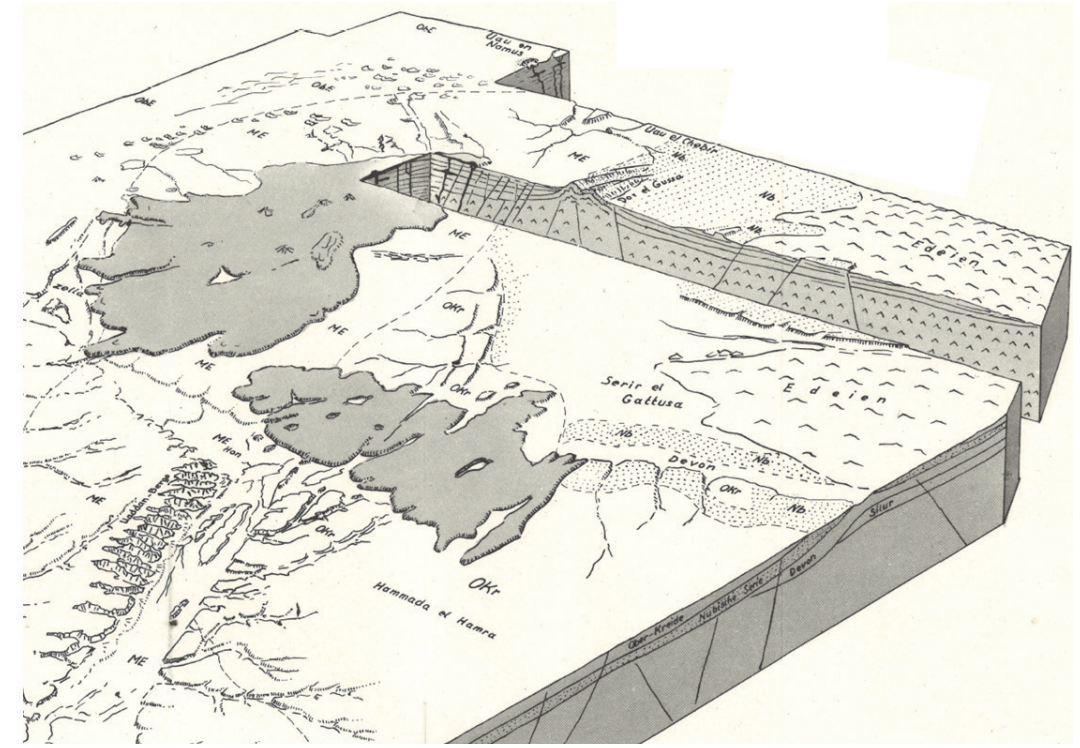

Figure 2: Detail of the geologic block diagram of Libya depicting a major dry valley south of the Big Sirte, the tectonic Djofra Graben structure. The widespread young basaltic layer of Jebel Sauda and Jebel Haruj es Sauda unconformably overlies elder deposits. View in southern direction. Abbreviation of geologic formations: $\mathrm{OKr}$ $=$ Late Cretaceous, $\mathrm{Nb}=$ Nubian Formation, $\mathrm{ME}=$ Middle Eocene, $\mathrm{ObE}=$ Late Eocene. ${ }^{36}$ (Courtesy of German Geological Society).

Quaternary flexures in the same direction. Important volcanic activity occurred at the end of the Tertiary until Recent times and some faults still show seismic activity.

The explanations of subsurface geology and tectonics relevant for military geology follow the observations of the German geologists Georg Knetsch and Friedrich-Karl Mixius, who took part in the counter-intelligence campaign of the German Abwehr in Libya. ${ }^{37}$ The subsurface of the Libyan Sahara consists of openly folded and faulted marl and limestone of Cretaceous to Tertiary age. Weathering of clay stone and marlstone under desert conditions rapidly forms powdery soils, which are mostly cemented and therefore protected by a hard layer. Sand is not abundant in the central Sahara. However, huge dune complexes were formed toward Egypt (Great Sand Sea) and in the southwest of Libya, such as Idehan Murzuq and Ubari Hamada (high rocky plateau, often with scarps), serir (gravel desert), and occasionally graret, large depressions with several dm-thick powdery soil cemented by a thin layer of coarse sand or salt (fesh-fesh) prevail in the central Sahara. Sebakha, depressions filled with fine sand and enriched with salt, occur in addition to single dunes and larger dune complexes. These saltpans are either terminal lakes occasionally charged by flowing water or owe their existence to groundwater evaporation through capillary ascent. 


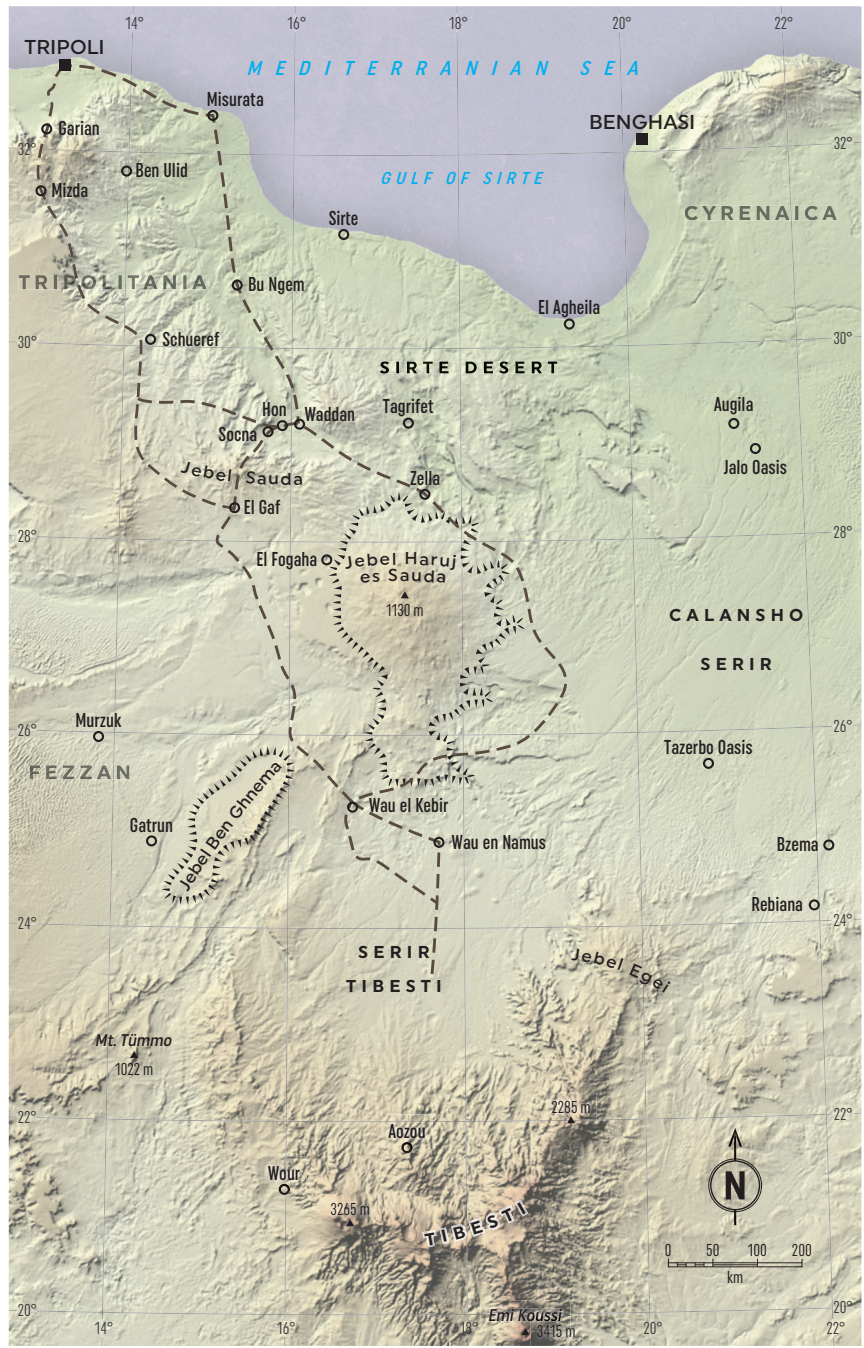

Figure 3: Map of the reconnaissance routes of Sonderkommando Dora in 1942. Route of Technical Reconnaissance Group East, east of Jebel Haruj es Sauda, and route of Technical Reconnaissance Group West, west of Haruj (modified later ${ }^{38}$ ).

As a consequence of the young tectonic flexures of the northern Cyrenaica, the formations were tilted slightly northward, paralleling the coast, and a new water divide came into existence in an east-southeast direction. Whereas terraces and fluvial deposits indicate former cycles of erosion and sedimentation, a younger generation of dry valleys pronounces the morphological tilt of the northern Cyrenaica. 
The importance of the knowledge of the groundwater situation of the central Sahara is threefold: first for the former colonial economy; second for knowledge on climate change during the last 10000 years; and third for local water supply in the desert. ${ }^{39}$ Local occurrence of deep thermal groundwater is related to young volcanism and southeast-trending faults and graben structures, such as hot springs of the Djofra Graben near Djebel el Sauda or at the Wau an Namus volcano. The widespread first groundwater horizon (aquifer), which is close to the subsurface, is the most important aquifer for potable water supply. It supplies the oases, where marginal lakes of the dune complexes are charged from occasional precipitation along wadis. Using radar satellite images, it is now possible to identify channels of former meandering rivers, which today are overlain by meters to tens of meters of sand. Groundwater below sand dunes is best protected against evaporation. Groundwater of this first (upper) aquifer is on the one hand charged from precipitation in the higher mountains such as the up to $3000 \mathrm{~m}$ high faulted Nubian Sandstone (overlying the crystalline basement) Tibesti Mountains in the south, and on the other hand by fossil groundwater from greater depths (artesian waters).

Landscape units, which were mapped by the geologists of the Sonderkommando Dora in their route maps at a scale of 1:200 000 included hamada (high rocky plateau, often with scarps), serir (gravel desert), graret (depression, basin), sebakha (salty marsh, bog), fesh-fesh (soft powdery chalk or clay), ergs (idehan; areas of shifting sand dunes) and dunes. Airborne and field excursions in the Fezzan, between Idehan Ubari and Idehan Murzuq, revealed an east-west-trending plateau, the Hamada of Murzuq, followed up eastward by a serir. Between Hon in the northwest and the Djebel Eghei in the southeast, basaltic rocks filled the prominent southeast-trending tectonic graben, which formed the hills and rocky plateaus of Jebel Sauda, Jebel Haruj es Sauda, Wau en Namus and Jebel Eghei. The sand and gravel plain of Serir Kalancho borders Jebel Haruj es Sauda to the east (Figure 3).

\section{Sonderkommando Dora}

Due to these geographical conditions, the 100-person strong Group c reconnaissance company under the command of Dr Otto Schulz-Kampfhenkel was divided into two patrol teams (Technical Group East and Technical Group West). These two teams were active from May-December 1942 and were ordered to perform cartographic mapping of expedition routes at a 1:200 000 scale, providing military geology maps including description of natural obstacles, water supply and the description of trafficability, and concluding major through lines (Figure 3).

Sonderkommando Dora was commanded by Air Force Colonel Herbert Haeckel and had company status. It consisted of a military group of about 100 personnel and a scientific unit of about 10 military geoscientists, including geographers, cartographers, geologists, astronomers, meteorologists and road specialists. The main mission of this command was a military geoscientific one, and, although the command was fit for action, combats had to be avoided at all circumstances. The military scientific teams were fully motorised and supported by airplanes for reconnaissance flights. ${ }^{40}$ 
Sonderkommando Dora's equipment consisted of 25 trucks and cars including 15 Volkswagens (VW) with broad (balloon) tires, two light armoured scout cars, and airplanes such as one (armoured) Heinkel He 111, one Henschel 126, two "Weihen", one Fieseler Fi 156 Stork ("Fieseler Storch"), several gliders and a big two-propeller aircraft. Their armaments consisted of only two light guns of the armoured scout cars and infantry weapons such as MG 34 machine guns, rifles, submachine guns and pistols. In accordance with Italian High Command, Sonderkommando Dora had its logistic support camp at Hon, $500 \mathrm{~km}$ south-southeast of Tripoli. The Hon airport Radio station had contact with Berlin headquarters as well as with smaller radio stations of Sonderkommando Dora's technical teams. The commanding officer and geographer Dr Otto Schulz-Kampfhenkel, a reserve lieutenant of the German Air Force, was also the head of the military geoscientific staff. ${ }^{41}$

Many of the geoscientific staff had no military ranks and were therefore termed 'Sonderführer', which was a civil rank somehow equivalent to an officer. All were trained in the use of pistols, rifles and machine guns. These scientific personnel of Sonderkommando Dora were deployed into two technical groups, Technical Group East and Technical Group West, and consisted of the following persons:

- Lieutenant Dr Ing. Walter A Brucklacher (pilot and aerial photo interpreter of the ZEISS company);

- Dr Rudolf Fritsch (zoologist and aerial photo interpreter);

- Dr Alfons Gabriel (geographer and medical doctor);

- Sonderführer Dr Fritz Höhndorf (meteorologist);

- Captain Prof. Dr Helmuth Kanter (geographer and medical doctor);

- Sonderführer Dr Georg Knetsch (geologist);

- Sonderführer Dr Walter Knörlein (road construction from VW company);

- Non-commissioned officer Dr Friedrich Karl Mixius (geologist);

- Private Dr Wolfgang Pillewizer (topographer and cartographer);

- Sonderführer Dr Nikolaus Benjamin Richter (astronomer, routes);

- Lance corporal E Teichgräber (astronomer);

- Lieutenant Dr Hans Rhotert (ethnologist, archaeologist, Sahara expert and navigator);

- Lieutenant Dr Otto Schulz-Kampfhenkel (geographer and zoologist); and

- Dr Ludwig GA Zöhrer (zoologist). ${ }^{42}$

Two pilots of this group, Lance Corporal Drevermann and Lieutenant Dr Frowein, were experts for gliders. Three photographers were responsible for processing aerial photographs and three draughtsmen designed the route maps. A few personnel served both the military group as well as the scientific group, such as the geographer and medical doctor, Dr Alfons Gabriel, and the ethnologist, archaeologist and navigator, Lieutenant Dr Hans Rhotert. 
When Sonderkommando Dora's mission in Libya ended and the teams returned to Germany in January 1943, this command was not closed down but functioned as an administrative headquarters with battalion status with Major Dr Fritz Gericke in command. From April 1943 to the end of the war, the (former African) research group was termed 'Forschungsstaffel z.b.V.', again headed by Dr Otto Schulz-Kampfhenkel. The abbreviation 'z.b.V.' was short for "zur besonderen Verwendung" meaning for the special use of high military commands or for special duty. Detailed information on the use of the Forschungsstaffel z.b.V. in the European theatres is available on demand from the author. ${ }^{43}$

\section{Reconnaissance in Libya 1942}

The aim of Sonderkommando Dora was to reconnoitre central and southern Libya from Jebel Sauda near Hon in the north to Jebel el Dora in the south. For this purpose, two reconnaissance teams were formed, Eastern Patrol and Western Patrol, each comprising ten persons, seven wheeled vehicles and airplanes. The Eastern Patrol reconnoitred the routes east of Jebel Haruj es Sauda via Wau en Namus to Bir Bu Haschischa; the Western Patrol reconnoitred the Fezzan, from Murzuq to Gatrun and Jebel Ben Gnema (Figure 3). Both patrols had to:

- produce cartographic maps of all important routes crossing the Sahara at a scale of 1:200 000;

- map military geology information on water supply, trafficability and natural obstacles, such as dunes and hilly areas (hamada); and

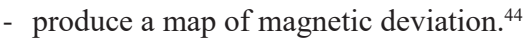

The expedition routes southeast of Hon, located north of Jebel Sauda, comprised Fezzan west of Murzuq, Jebel Haruj es Sauda and extended to the Tibesti Massif (Tibesti Mountains) in the south. Topographic mapping was based on astronomic measurements, geodetic measurements, route sketches and mapping of the landscape along the routes. In the Murzuq Basin, four sheets at a scale of 1:200 000 were compiled. Based on geologic mapping and reconnaissance flights, a morphologicgeologic overview map at a scale of 1:1 000000 was designed, depicting hamada (stony plain), serir (gravel desert), dunes and oases. Oases were important for the calculation of water supply and condition of hamada, while serir and dunes were important for the calculation of off-road trafficability of armed forces.

The routes along the serir between Jebel el Sauda in the north and Wau el Kebir in the south were mapped by the Technische Gruppe, Erkundung West in six sheets at a scale of 1:200 000, which were compiled at a scale of 1:1 million and identified serir, dunes and oases. Similarly, the routes around the hilly hamada of Jebel Haruj es Sauda were mapped in nine sheets at a scale of 1:200 000, which were compiled at a 1:1000 000 scale, identifying hamada, serir, dunes and oases. In total, Sonderkommando Dora provided two maps at a 1:25 000 scale, one map at a 1:50 000 scale, 20 maps at a 1:200 000 scale and three overview maps at a scale of 1:1 million from March to June 1942, i.e. within only four months. ${ }^{45}$ 

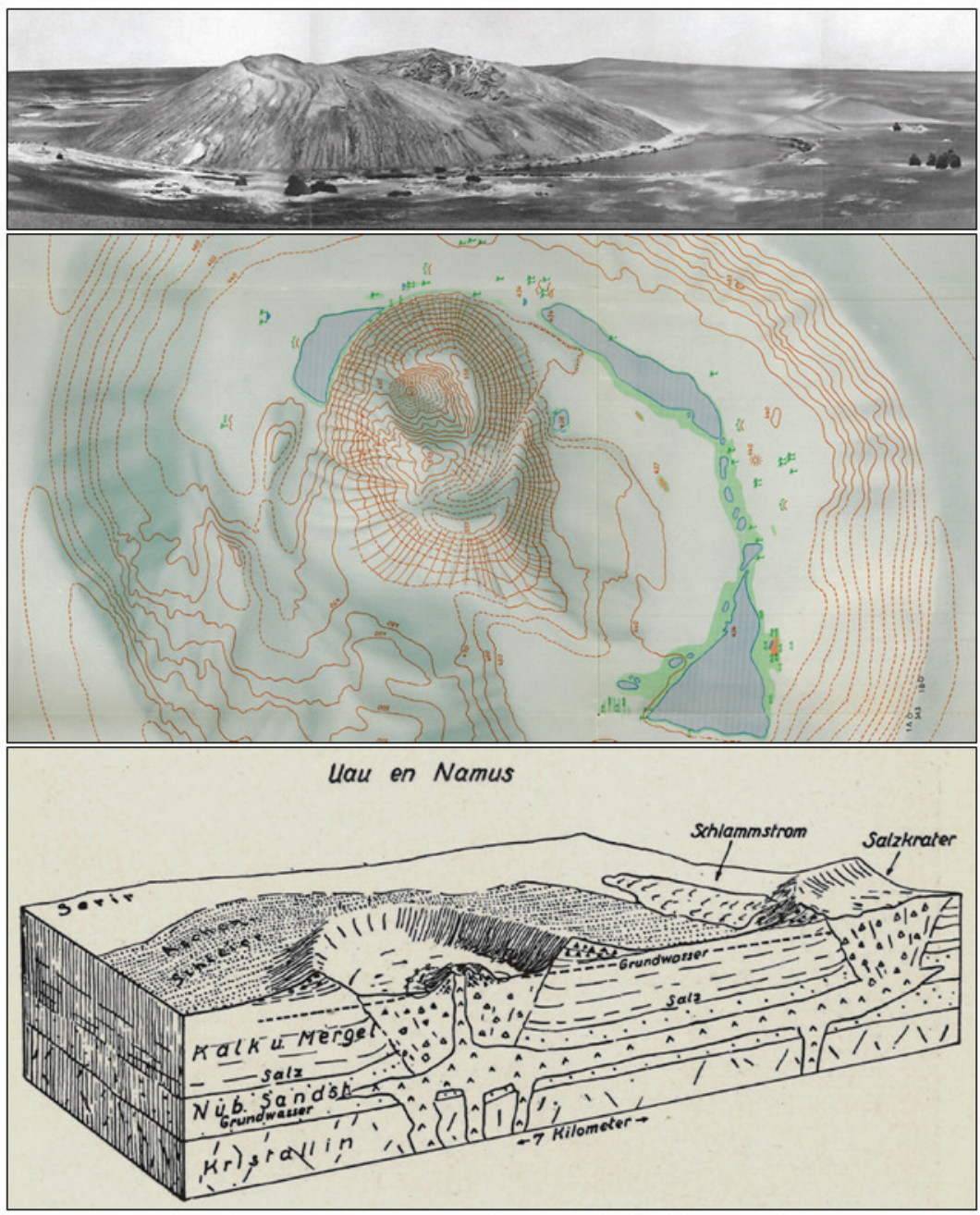

Figure 4: Oblique aerial photo of Wau en Namus (above), the geodetic survey of it in 1942 (middle) ${ }^{46}$ and a geologic block diagram of the volcano and its crater (below). ${ }^{47}$ Note: meaning of German explanations: Schlammstrom (mud flow), Salzkrater (salt crater), Kristallin (crystalline basement), Nub. Sandst. (Nubian Sandstone), Kalk und Mergel, Salz (limestone and marl, salt), Grundwasser (ground water), Aschenschleier (thin cover of volcanic ash) (Courtesy of German Geological Society). 

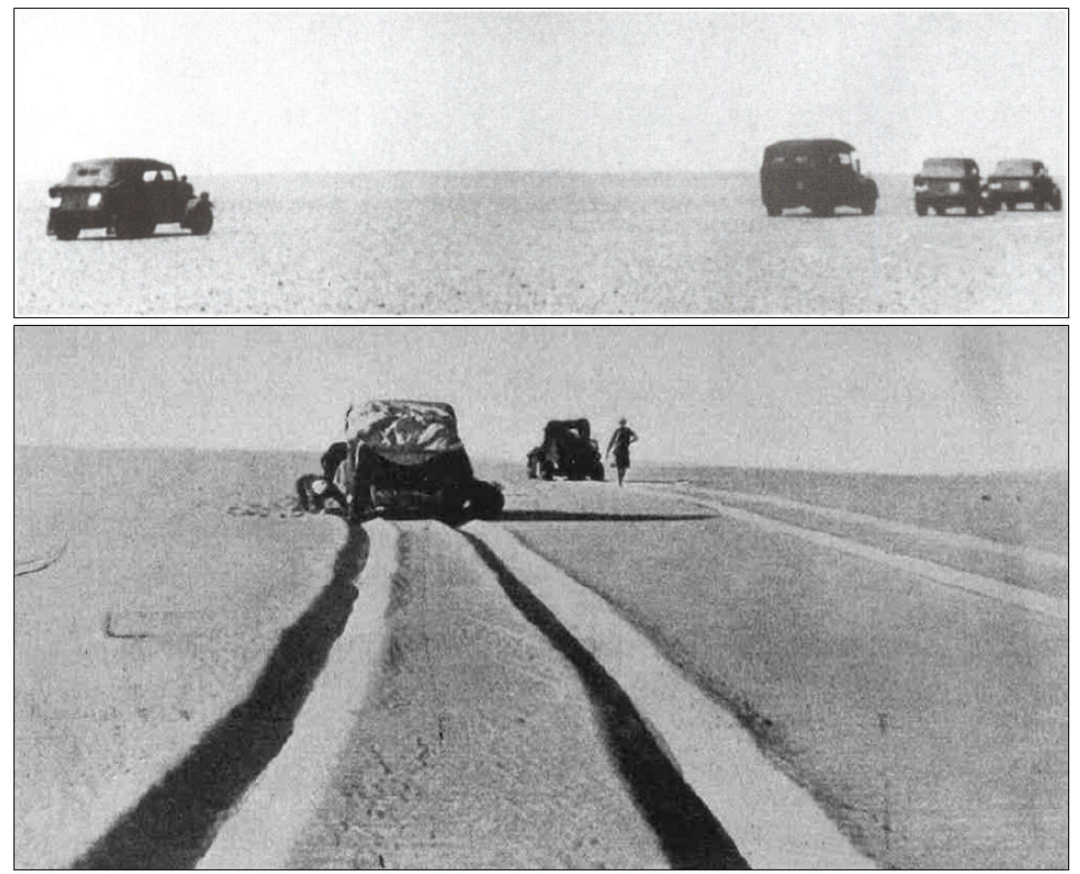

Figure 5: Above: Good going on hard sand of the Serir Kalancho, east of Jebel Haruj es Sauda (1942). ${ }^{49}$ (Courtesy of Michal Farin, Belleville Publishers). Below: Bad going on soft sand. ${ }^{50}$

A major result of the six-week military geoscientific reconnaissance in central and southern Libyan Sahara was cartographic maps of important routes at a scale of 1:200 000, including details on trafficability, potential through routes, natural obstacles, such as dunes and hamada, maps of potential water supply, maps of magnetic deviation, and reports. ${ }^{48}$

Figures 5 and 6 show examples of trafficability experienced by the technical groups of Sonderkommando Dora. Figure 5 (above) depicts wind-blown hard sand in the Serir Kalancho, north of Kufra Oasis, which is firm and allows good going versus the common situation when vehicles get stuck in soft sand (Figure 5, above). 

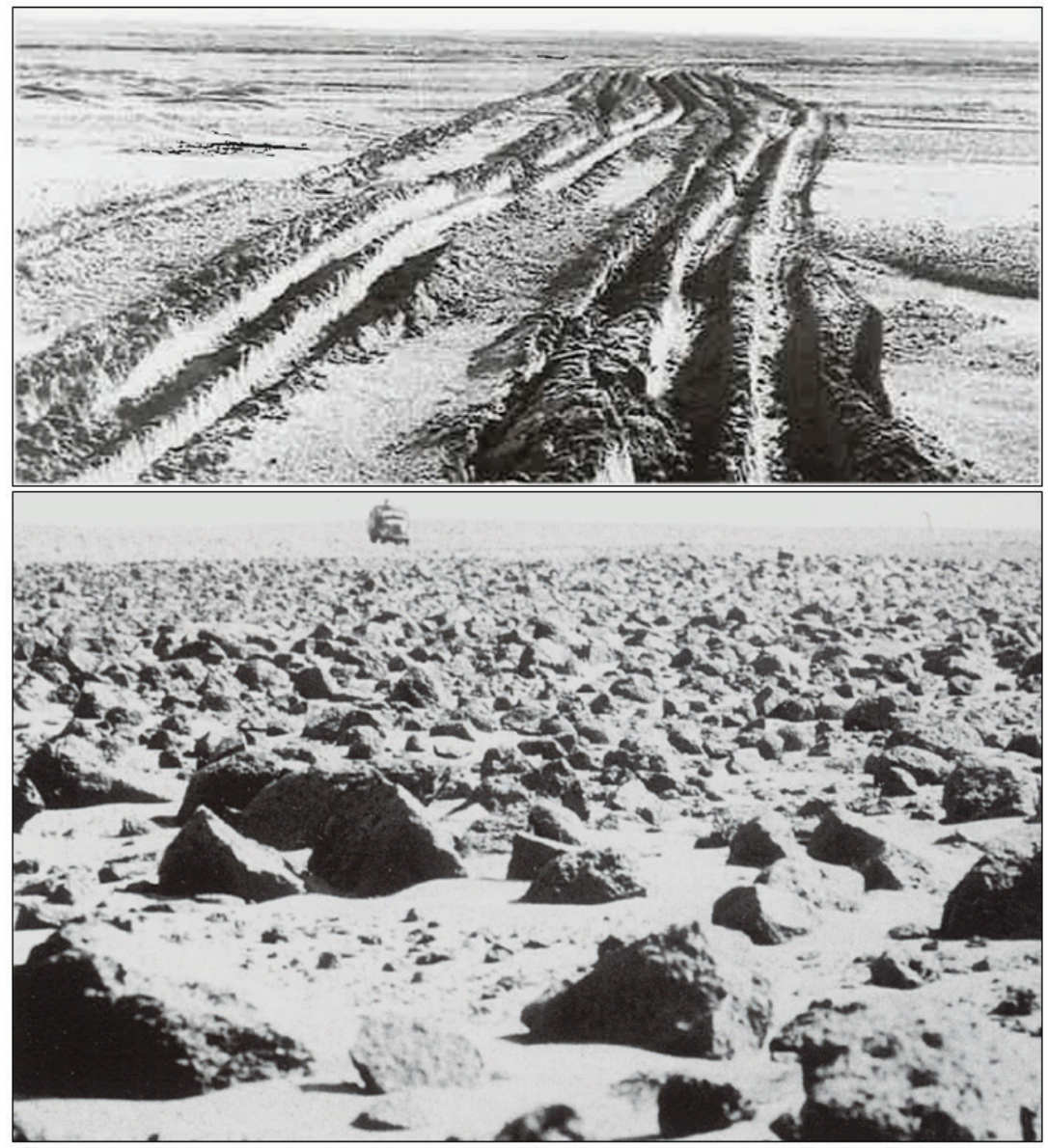

Figure 6: Above: Bad trafficability of the marly dust plain northeast of Wau en Namus (10 July 1942). Below: Bad trafficability in the Black Haruj, which is a lava-stone desert covered by basalt blocks (13-16 July 1942). ${ }^{51}$ (Courtesy of Michal Farin, Belleville Publishers).

Figure 6 depicts two examples of bad going depending on the subsurface geology. Due to the dry climatic conditions, the marls of Late Cretaceous to Tertiary Age turn to marly dust that is hardly passable (above). The deeply incised volcanic hills of Jebel Sauda (south of Hon) and the Jebel Haruj es Sauda consist of boulders of disintegrated basaltic lava streams, which can hardly be passed by vehicles (Figure 6, below). The map in Figure 7 is an interpreted geologic map at a 1:1 million scale and was the basis for the field work within topographic sheets at a scale of 1:200 000 . 

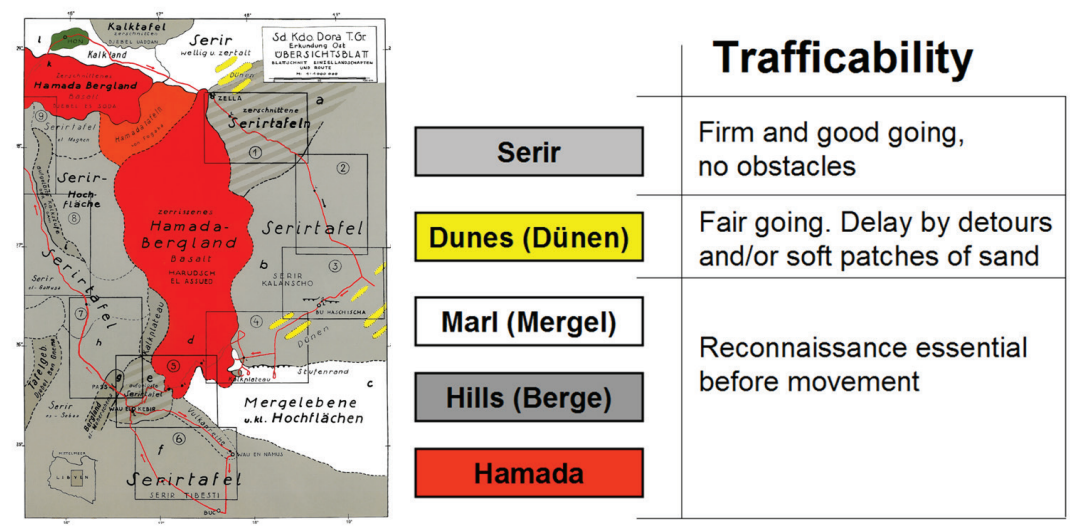

Figure 7: Classification of landscape resulting in a general overview on trafficability based on the rock formations depicted in a geologic map that was evaluated by field expeditions and reconnaissance flights. ${ }^{52}$

Serir can be described in general as a plateau-like gravel desert without any obstacles; hence, it allows for good going. Dunes can either be passed at high speed or could cause delays by detours and/or local patches of soft sand (Figure 5). Hamada, in general, forms high rocky plateaus, often with scarps, where reconnaissance is essential before movement. This is particularly the case when it consists of basalt deposits, the lava flows of which disintegrate and turn to a landscape consisting of weathered gravel and boulders. Along the widespread occurrence of Late Cretaceous to Tertiary, formations of deeply weathered marls caused problems with trafficability (Figure 6).

\section{Conclusions}

In 1941, at a time when the Italian topographic maps were not accurate enough for assessing routes from Chad to Libya, Sonderkommando Dora substantially enhanced topographic maps at various scales and prepared special military geoscientific maps of this border area to assist the German Armed Forces High Command in decisionmaking. As far as is known, these special maps were never used by Axis troops for tactical purposes - although it cannot be ruled out that the maps provided general information on the proximity of the German Africa Corps, the Panzer Group Africa and of the Panzer Army Africa, respectively, and also of the retreating Army Group Africa.

\section{Endnotes}

\footnotetext{
${ }^{1}$ NB Richter. Unvergessliche Sahara. 3. Auflage, Leipzig: Brockhaus, 1953.

${ }^{2}$ NB Richter. Unvergessliche Sahara. 2. erweiterte und ergänzte Auflage. München: Belleville, 1999.
} 
${ }^{3}$ NB Richter. Auf dem Wege zur Schwarzen Oase. 2. erweiterte und ergänzte Auflage. München: Belleville, 2003.

${ }^{4}$ M Rolke. Die Karten des ,Sonderkommando Dora”. 23 Karten. München: Belleville, 2003.

${ }^{5} \mathrm{G}$ Knetsch. Mitteilung über neue Beobachtungen zur Geologie der Marmarica (Nord-Libyen). Geologische Rundschau 33. 1942. 409-414; G Knetsch \& F.-K Mixius. Beobachtungen in der libyschen Sahara. Geologische Rundschau 38. 1950. 40-59.

${ }^{6}$ W Pillewizer \& N Richter. Beschreibung und Kartenaufnahme der Krateroase Wau en-Namus in der zentralen Sahara. Petermanns Geographische Mitteilungen, Ergänzungsheft 264, Kartographische Studien (Haak-Festschrift), 1957, 303-320; see also W Pillewizer \& B Jüptner. Routenaufnahme und Satellitenbildkarte. Kartographische Nachrichten 43. 1993. 174-181; W Pillewizer. Als Kartograph im Krieg. Informationen des Militärischen GeoDienstes 49, 1995. 1-18.

${ }^{7}$ H Häusler. Forschungsstaffel z.b.V. - Eine Sondereinheit zur militärgeografischen Beurteilung des Geländes im 2. Weltkrieg. MILGEO 21. 2007. 1-209; see also H Häusler. The "Forschungsstaffel z.b.V.", a special geoscientific unit of the German counter military intelligence service during the Second World War. In H Häusler \& R Mang (eds), International handbook military geography, Vol. 2. Proceedings of the 8th International Conference on Military Geosciences, June 15-19, 2009. Vienna: Redaktion Truppendienst, Institute of Military Geography, Ministry of Defence and Sports. 2011. 276-286; see also S Flachowsky \& H Stoecker (eds). Vom Amazonas an die Ostfront. Der Expeditionsreisende und Geograph Otto Schulz-Kampfhenkel (1910 - 1989). Köln: Böhlau, 2011.

${ }^{8}$ EA Schmidl. Die ,Takoradi Air Route” - eine strategisch bedeutsame Nachschubroute der Alliierten im Zweiten Weltkrieg. Österreichische Militärische Zeitschrift LI(6). 2013. 640-653.

${ }^{9}$ Ibid.

${ }^{10}$ Häusler, Forschungsstaffel z.b.V. op. cit.

${ }^{11}$ W Kaufmann. Das „Sonderkommando Dora” der Abwehr im Einsatz in der Libyschen Wüste. Die militärgeographischen Erkundungen der Technischen Gruppe Ost im Juli 1942. In JW Schmidt (ed), Geheimdienste in Deutschland: Affären, Operationen, Personen. Geheimdienstgeschichte, Band 4, 2. Auflage. Ludwigsfelde: Ludwigsfelder Verlagshaus, 2015, 226-262.

${ }^{12}$ Schmidl op. cit.

${ }^{13} \mathrm{H}$ Spaeter. Die Brandenburger - eine deutsche Kommandotruppe zbV 800. 3. Auflage. Düsseldorf: Dissberger, 1992; see also F Kurowski. Deutsche Kommandotrupps 1939-1945. »Brandenburger « und Abwehr im weltweiten Einsatz. 3. Auflage. Stuttgart: Motorbuch Verlag, 2004; A Molinari. Desert raiders: Axis and Allied Special Forces 1940-43. Oxford: Osprey Publishing, 2007; G Williamson. German Special Forces of World War II. Oxford: Osprey Publishing, 2009. 
${ }^{14}$ Molinari op. cit.; see also K Gross, M Rolke \& A Zboray. Operation Salam. László Almásy's most daring mission in the Desert War. München: belleville, 2013.

${ }^{15}$ Spaeter op. cit.; see also Williamson op. cit.

${ }^{16}$ Gross et al. op. cit.

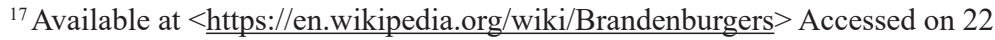
March 2017.

${ }^{18}$ JM Kolisch. Preliminary information report, Prisoner Franz Seubert, Lieutenant Colonel, Abwehr, 30 November 1945. Headquarters Intelligence Center, 6825 HQ and HQS Company, Military Intelligence Service in Austria, APO 777, US Army. Available at $<$ http://numbers-stations.com $/ \mathrm{cia} / \mathrm{German} \% 20$ Intelligence $\% 20$ Service $\% 20 \% 28$ wwii $\% 29 \% 2 \mathrm{C} \% 20 \% 20 \mathrm{Vol} . \% 203 /$ GERMAN\%20INTELLIGENCE\%20SERVICE\%20\%28WWII\%29\%2C\%20 \%20VOL.\%203 0001.pdf $>$ Accessed on 22 March 2017.

${ }^{19}$ Gross et al. op. cit.

${ }^{20}$ Häusler, Forschungsstaffel z.b.V. op. cit., p. 11.

${ }^{21}$ Ibid.

${ }^{22}$ Ibid.

${ }^{23}$ Gross et al. op. cit.

${ }^{24} \mathrm{~K}$ Gross, R Chiarvtto \& B O'Caroll. Incident at Jebel Sherif: In search of the first clash of the Special Forces 1941/2009. Koblenz: Verlag Kuno Gross, 2009; see also $<$ https://de.wikipedia.org/wiki/Gerhard_von_Schwerin $>$ Accessed on 22 March 2017.

${ }^{25}$ With order of "Abw Nr. 1290/42 g.Kdos I H West".

${ }^{26}$ With order of "Amt Ausland/Abwehr I: Sonderkommando Dora Nr. 23/42 g.Kdos".

${ }^{27}$ Kaufmann op. cit.

28 "Leichter Panzerspähwagen, Sd.-Kfz. 222".

${ }^{29}$ Available at $<$ https://de.metapedia.org/wiki/Leipzig_Konrad_von $>$ Accessed on 14 May 2017.

${ }^{30}$ Spaeter op. cit.; see also Kurowski op. cit.; Molinari op. cit.; Kaufmann op. cit.

${ }^{31}$ JM Kolisch. First detailed interrogation report, Source Franz Seubert, Lieutenant Colonel, Abwehr. 2 January 1946, Headquarters Intelligence Center, 6825 HQ and HQS Company, Military Intelligence Service in Austria, APO 777, US Army. Available at $<$ http://numbers-stations.com $/$ cia/German $\% 20$ Intelligence $\% 20$ Service $\% 20 \% 28$ wwii $\% 29 \% 2 \mathrm{C} \% 20 \% 20 \mathrm{Vol} . \% 203 /$ GERMAN\%20INTELLIGENCE $\% 20$ SERVICE $\% 20 \% 28$ WWII $\% 29 \% 2$ C $\% 20$ \%20VOL.\%203 0001.pdf $>$ Accessed on 22 March 2017.

${ }^{32} \mathrm{H}$ Römer-Heitmann. German special operations in Africa during WW2. The South African Military History Society: Cape Town Branch Newsletter No. 403, October 2012. Available at $<\underline{\text { https: } / / \text { samilitary history.org/12/c12octne.html }>}$ Accessed on 1 August 2017; see also Gross et al., Operation Salam op. cit.; Schmidl op. cit.

${ }^{33}$ Generalstab des Heeres, Abteilung für Kriegskarten- und Vermessungswesen (IV. Mil.-Geo.). Militärgeographische Beschreibung von Tunis, abgeschlossen am 10. Oktober 1941, Nur für den Dienstgebrauch. 
${ }^{34}$ Kanter, H. Libyen - Libya. Eine geographisch-medizinische Länderkunde/A geomedical monograph. Series of monographs of the Heidelberger Akademie der Wissenschaften, mathematisch-naturwissenschaftliche Klasse, Berlin: Springer, 1967.

${ }^{35}$ T Schlüter. Geological Atlas of Africa. 2nd four-coloured revised and enlarged ed. Berlin: Springer, 2006; see also Knetsch \& Mixius op. cit.

${ }^{36}$ Knetsch \& Mixius op. cit.

${ }^{37}$ Ibid.

${ }^{38}$ Richter, Unvergessliche Sahara 2 op. cit.; see also Häusler, Forschungsstaffel z.b.V. op. cit.

${ }^{39}$ Knetsch \& Mixius op. cit.

${ }^{40}$ Häusler, Forschungsstaffel z.b.V. op. cit.

${ }^{41}$ Ibid.

${ }^{42}$ Ibid.

${ }^{43}$ Ibid.

${ }^{44}$ Ibid.

${ }^{45}$ Ibid.

${ }^{46}$ Pillewizer \& Richter op. cit.

${ }^{47}$ Knetsch \& Mixius op. cit.

${ }^{48}$ The results of the two reconnaissance groups of Sonderkommando Dora, Technical Group East and West, were provided one month after their mission in Libya, summarised in three reports: Technical Sonderkommando Dora, Technische Gruppe: Ergebnisse von Geländeerkundungen in Mittel- und Südlibyen. Bericht 1 (T.G. 1/42): Vorläufiger Ergebnisbericht über eine Erkundung in der ostwärtigen und mittleren Libyschen Sahara zwischen der Oase Hon und der nördlichen Serir Tibesti (Erkundung Ost vom 5.7.42 bis 24.7.42) mit 5 Karten (21 Blättern), 6 Landschaftsskizzen und 132 photographische Aufnahmen. 83 S., O. U. 15. August 1942 a. Sonderkommando Dora, Technische Gruppe: Ergebnisse von Geländeerkundungen in Mittel- und Südlibyen. Bericht 2 (T.G. 2/42): Vorläufiger Ergebnisbericht über eine Erkundung in der mittleren Libyschen Sahara zwischen der Oase Hon und dem Wau el Kebir (Erkundung West vom 5.7.42 bis 30.7.42) mit 5 Karten (13 Blätter) und 39 photographische Aufnahmen, O. U., 15. August 1942 b. Sonderkommando Dora, Technische Gruppe: Ergebnisse von Geländeerkundungen in Mittel- und Südlibyen. Bericht 3 (T.G. 3/42): Vorläufiger Bericht über die Nachschubwege nach Südlibyen (Westteil; mit 1 Karte und Entfernungstabelle) und allgemeine Übersichtskarten zu den Berichten der Erkundungen Ost und West (T.G. 1/42 und T.G. 2/42). 31 S., O. U. 15. August 1942 c. These reports and the original maps and documents are archived in Bundesarchiv-Militärarchiv Freiburg/ Breisgau (RW 733).

${ }^{49}$ Richter, Unvergessliche Sahara 2 op. cit.

${ }^{50}$ This figure has been published by LE Almásy. Schwimmer in der Wüste. Auf der Suche nach der Oase Zarzura. 2. verbesserte und ergänzte Auflage. Innsbruck: Haymon, 1997, 99. It was first published by Generalstab des Heeres.

Militärgeographische Beschreibung von Nordost-Afrika. Berlin, Abteilung für 
Kriegskarten und Vermessungswesen, IV. Mil.-Geo., 1940. For more details on László Ede Almásy (1895-1951), see Gross et al. Operation Salam op. cit.

${ }^{51}$ Richter, Unvergessliche Sahara 2 op. cit.

${ }^{52}$ Rolke $o p$. cit; see also Häusler, The "Forschungsstaffel z.b.V.", a special geoscientific unit ... op. cit. 